This is a self-archived version of an original article. This version may differ from the original in pagination and typographic details.

Author(s): DeVaro, Jed; Kauhanen, Antti; Valmari, Nelli

Title: Internal and External Hiring

Year: 2019

Version: Accepted version (Final draft)

Copyright: (c) The Author(s) 2019

Rights: In Copyright

Rights url: http://rightsstatements.org/page//nC/1.0/?language=en

Please cite the original version:

DeVaro, J., Kauhanen, A., \& Valmari, N. (2019). Internal and External Hiring. Industrial and labor relations review, 72(4), 981-1008. https://doi.org/10.1177/0019793919842810 


\title{
INTERNAL AND EXTERNAL HIRING ${ }^{1}$
}

\author{
by
}

Jed DeVaro, Antti Kauhanen, and Nelli Valmari

\begin{abstract}
Using large-scale, linked, employer-employee, Finnish panel data, the authors examine firms' internal-versus-external hiring decisions more comprehensively than has prior literature. The results show that vacancies in job hierarchies are filled more often by horizontal moves than by promotions. Most horizontal moves are external and within the same job functions, so that internally-promoted workers face external competitors occupying higher job levels. Compared to internally-promoted workers, external and internal horizontal hires have stronger observable ability indicators (e.g., education, experience, prior work history) but weaker job performance in the year preceding the transfer. Internal and external horizontal hires have similar job histories.
\end{abstract}

Keywords: internal hiring, external recruitment, promotions, lateral moves, work history, job assignments, turnover

\footnotetext{
${ }^{1}$ Jed DeVaro is a Professor at California State University. Antti Kauhanen is a Research Director at the Research Institute of the Finnish Economy (ETLA) and a Professor at Jyväskylä University School of Business and Economics. Nelli Valmari is a Researcher at the Research Institute of the Finnish Economy (ETLA). We thank Emilio Castilla, four anonymous reviewers, Hugh Cassidy, Xiaodong Fan, Oliver Gürtler, Michael Waldman and seminar participants at Kansas State University, Universidad Carlos III de Madrid, 2017 IEA World Congress, 2017 LERA annual meeting, 2015 Trans-Pacific Labor Seminar, Finnish Economic Association XXXVII Annual Meeting, COPE 2015, University of Jyväskylä, and VATT seminar for helpful comments. The computer programs used to generate the results presented in the paper are available from Antti Kauhanen at antti.kauhanen@etla.fi. The data are proprietary and thus we are unable to make them publicly available. Contact Antti Kauhanen for information on how to gain access to the data.
} 
Vacancies regularly arise throughout organizational job hierarchies, and employers must decide whether to fill them via internal hires or external recruits (Bidwell and Keller 2014). Most research on that subject either relies on data from a single firm (e.g. Baker et al. 1994, Bidwell 2011, Bidwell and Keller 2014), or concentrates on a specific job type, often near the top of the hierarchy (e.g. Agrawal et al. 2006). Such data narrow the scope of the conclusions that can be drawn. On the other hand, broad data sets that span multiple firms and jobs usually lack measures of occupations and job levels that allow meaningful cross-firm comparisons; the job levels in one firm might not readily correspond to those in another (see e.g. Frederiksen et al. 2015, p.323-324). Using a large, linked, employer-employee panel data set from Finland that overcomes those challenges, we re-evaluate previous findings on internal-versus-external hiring and document new empirical facts concerning the characteristics of external hires prior to their hiring.

We start by re-evaluating the following results from prior research:

1) firms have a preference for internal promotion, as opposed to external recruitment (Baker et al. 1994, Lazear and Oyer 2004, Kauhanen and Napari 2012, DeVaro and Morita 2013, Bidwell and Mollick 2015);

2) that preference is strongest at the top of the job hierarchy (Royal and Althauser 2003, Audas et al. 2004, Lazear and Oyer 2004, Kauhanen and Napari 2012);

3) external hires have higher education levels than internally-promoted workers (Baker et al. 1994, Bidwell 2011, Kauhanen and Napari 2012);

4) external hires have higher levels of experience than internally-promoted workers (Baker et al. 1994, Bidwell 2011, Kauhanen and Napari 2012);

5) most external moves are horizontal rather than vertical (Bidwell and Mollick 2015). Henceforth, we refer to these prior results using the preceding numbers.

Re-evaluating prior evidence using broader data allows greater confidence in developing theory and in providing recommendations to workers and organizations. It also responds to other scholars' calls. Waldman (2013) argues that more empirical evidence on internal and external career mobility would facilitate a more fruitful and focused development of theory. Similarly, Baker and Holmström (1995) argue that results from a few case studies should not be used as empirical targets for theorists, even though theory in this literature has been heavily influenced by precisely such case studies. More generally, Hamermesh (2007) argues that ideas should be empirically tested with several data sets from different institutional settings.

In terms of new empirical facts, we expand on the literature in two ways. First, motivated by the earlier finding that most external moves are horizontal, we investigate whether external hires into a given job function originated in the same job function, or a different one, prior to moving. 
Whereas firm-to-firm transitions that occur within a job function allow previously accumulated task-specific human capital to be productively employed, that is not so for transitions that occur across job functions. Prior research has emphasized the role of firm-specific human capital, and we broaden that discussion by considering occupation or task-specific human capital. The labor economics literature on human capital has increasingly focused on occupation and task-specific (as opposed to firm-specific) human capital, and we inform that literature with new results, thereby deepening our understanding of the role of occupation-specific human capital in the labor market.

Second, we examine how the internal-versus-external hiring decision relates to various measures of workers' prior career histories and to a job-specific worker performance measure derived from data on individual performance-related pay. This allows us to extend known results that external hires need better observable indicators of ability by considering a larger set of observable indicators of ability than education and experience. Our measures of work history and job-specific performance are typically unavailable to researchers and have not been used in prior work. But they are potentially important, because they capture dimensions of expected performance that are typically visible to employers (e.g., work history can be gleaned directly from applicants' résumés, except in the case of new labor-market entrants) and that can be expected to influence hiring decisions. Such information allows us to determine which dimensions of performance (including commonly studied measures like education and years of experience) are associated with a higher likelihood of filling vacancies externally rather than internally. Such an investigation complements recent research that reveals a connection between work history and wages for college graduates (Fan and DeVaro 2018).

\section{Related Literature}

Theoretical explanations for prior results 1 and 2 (i.e., firms have a preference for internal promotion that strengthens at the top of the job hierarchy) have focused mainly on firm-specific human capital (e.g. Bayo-Moriones and Ortín-Ángel 2006, Bidwell 2011, DeVaro and Morita 2013, Bidwell and Keller 2014) and worker incentives (Malcomson 1984, Chan 1996, Waldman 2003). Sometimes these explanations are combined with others; Bidwell (2011) combines firm-specific human capital and incomplete information; Bidwell and Keller (2014) explore the interaction of two factors: how firm-specific skills and information affect worker-job fit, and how promotions affect coworkers' incentives. Firm-specific human capital gives insiders a productivity advantage over outsiders, thereby increasing the relative appeal of internal hiring. Concerning incentives, promotion prospects encourage workers to exert effort (e.g. Lazear and Rosen 1981, Ghosh and Waldman 2010), or to invest in human capital (e.g. Prendergast 1993, Zábojník and Bernhardt 
2001, DeVaro et al. 2018). These incentives are weakened if the firm toughens its workers' competition by also hiring externally (Chan 1996). An incentives-based theoretical explanation for prior result 2 is offered in Ke et al. (2018); workers are externally hired into lower-level positions (where the anticipated rewards from promotions allow employers to pay lower wages) whereas external hiring is more expensive in higher-level positions.

Empirical evidence relating to prior result 1 is found in Bidwell and Mollick (2015), which uses data from a survey of MBA alumni in a leading U.S. business school to show that upward progression into a job with greater responsibilities is more likely to occur through internal promotion than external recruitment. Evidence of an internal hiring preference is provided in Baker et al. (1994), using personnel data from 1969 to 1988 in an American firm in financial services. Kauhanen and Napari (2012) replicate that evidence using a different sample (from 1981 to 2006) of the same data we use. Using Swedish matched employer-employee panel data, from 1970 to 1990, Lazear and Oyer (2004) provide evidence of an internal hiring preference. Using a 2004 survey of British establishments, DeVaro and Morita (2013) provide evidence of an internal hiring preference. Evidence relating to prior result 2 comes from Baker et al. (1994), Kauhanen and Napari (2012), Lazear and Oyer (2004) and the single-firm studies by Bidwell (2011) and Chan (2006). The main finding is that the share of external workers per job level shrinks at higher job levels.

Our evidence concerning prior results 1 and 2 contributes in three ways to the literature. First, we estimate the probabilities of different ways to fill existing vacancies, whereas prior studies (e.g. Bidwell and Mollick 2015) estimate the probability that workers experience different types of job changes. These two types of probabilities are closely related but are not the same. Our focus on how existing vacancies are filled thus offers a new perspective that complements prior studies. Second, we differentiate external hires by their job level in the originating job, which was not possible in the data sets used in earlier studies. ${ }^{2}$ Third, we examine how internal-versus-external hiring relates to job growth (i.e., whether jobs are growing, stable, or shrinking), which is new. Including these job-growth controls in the statistical model is important, because there is a mechanical relationship between job growth and how job vacancies are filled (e.g., if a job is growing, then external hiring is needed simply because the supply of internal candidates gets depleted). Therefore, excluding job-growth controls raises concerns of omitted-variables bias.

Prior results 3 and 4 (external hires have higher levels of education and experience than internally-promoted workers) find empirical support in Bidwell (2011), using personnel data from 2003 to 2009 in the U.S. investment banking arm of a financial services company. Bidwell finds

\footnotetext{
${ }^{2}$ In Kauhanen and Napari (2012) the information was available but was not used.
} 
that, compared to internally-promoted workers, external hires have higher levels of education and experience and are promoted faster. Baker et al. (1994) also document that external hires have higher levels of education and experience than internally-promoted workers. The same result is found in Kauhanen and Napari (2012). Although he does not consider education and experience, Chan (2006) presents complementary results consistent with external hires having higher ability. Using personnel data from 1986 to 1994 in a U.S. financial corporation, he shows that being an external hire, versus an internally-promoted worker, increases the promotion probability and the number of future promotions.

Firm-specific human capital offers a potential theoretical explanation for prior results 3 and 4 , i.e., external hires require more education and experience to compete with the internal candidates who possess firm-specific human capital. An alternative theoretical explanation concerns asymmetric learning, i.e., the idea that a worker's current employer is more able than competing employers to learn about that worker's ability. When one firm attempts to poach a worker from another, that worker's current employer (who has better information about that worker's aptitude than does the potential poacher) can make a counteroffer sufficient to retain the worker. Therefore, if the poaching firm successfully poaches the worker, it must mean that the worker's original employer felt that the worker was not worth retaining. This "winner's curse" phenomenon is well known in the literature (e.g. Greenwald 1986). Fear of the winner's curse implies that potential poachers require external hires to be that much better than internal candidates on observable dimensions of ability (e.g., education and experience). Greenwald (1986) shows that if incumbent employers have more accurate information about their workers' abilities than do competing employers, then firm changers are, on average, less able than stayers, conditional on observed characteristics. This implies prior results 3 and 4.

Given their inability to observe the ability of prospective hires, external employers rely on various observable indicators (or signals) of ability. The signals that the literature has focused on most heavily are job assignments, and particularly promotions (e.g. Waldman 1984, MacLeod and Malcomson 1988, Ricart i Costa 1988, Waldman 1990, Owan 2004, DeVaro and Waldman 2012). That literature focuses on the worker's most recent job, and although Bernhardt (1995) considers a multi-period promotion signaling model with potentially two promotions, the work history remains limited to a single firm. The work history that employers can glean from résumés is richer, and our analysis provides empirical evidence on the role of these more comprehensive work histories. Such inquiry has been neglected in the literature, apart from Fan and DeVaro (2018), which finds empirical evidence for a "job-hopping wage penalty" for college graduates but not high school graduates, interpreting that evidence as supportive of asymmetric employer learning for college 
graduates and symmetric learning for high school graduates. While Fan and DeVaro investigate how mobility affects wages, we study how employees entering a job through different channels differ in their job histories.

Although the signaling literature has focused most heavily on job assignments, other variables that employers observe can also signal worker ability. Examples include education, experience, age, and, if it happens to be known to prospective employers, even a worker's current wage. The notion that a worker's wage history may contain useful (to potential new employers) information about the worker's ability appears in the theoretical work of Bernhardt and Scoones (1993). In that analysis, firms pre-emptively offer high wages to their high-quality workers in an effort to discourage competing employers from collecting information about the quality of those workers (which would further bid up their wages or lead to them getting poached). Thus, a high wage is interpreted by the market as an indication that a worker is of high quality and well matched to his or her employer.

In related work, Frederiksen and Kato (2018) study the roles of different types of human capital for (internal and external) promotions to top executive positions using a matched employeremployee data set from Denmark (the IDA data). Defining a work-history variable measured as the number of "roles", or occupation/firm combinations, they find that a broad scope of human capital acquired inside the firm, as opposed to human capital acquired at other firms, is particularly beneficial for promotions to top executive positions. Unlike our analysis, theirs is limited to top executive positions and does not consider horizontal moves.

Prior result 5 (i.e., most external moves are horizontal rather than vertical) concerns horizontal moves, whereas most research on hierarchical mobility focuses on promotions. Although the literature on horizontal moves is relatively small, the topic is important because of recent growth in external hiring at all levels of the job hierarchy (Royal and Althauser 2003, Jacoby 2005). Examples of research on horizontal moves include Jin and Waldman (2016), Cassidy et al. (2016), Bidwell and Mollick (2015), Bidwell and Keller (2014), Bidwell (2011), Eriksson and Ortega (2006), Dohmen et al. (2004), and the related analysis of job rotation in Ortega (2001). See Bidwell and Mollick (2015) for empirical evidence on prior result 5.

Whereas firm specificity of human capital is helpful for understanding internal promotions, task-specificity is a more natural concept for understanding horizontal moves. Task-specific (or occupation-specific) human capital, which is portable across firms, has been increasingly emphasized in labor economics relative to firm-specific human capital (Gibbons and Waldman 2004, Gibbons and Waldman 2006, Kambourov and Manovskii 2009, Gathmann and Schönberg 2010, Cassidy 2017). When task-specific human capital is important, external horizontal moves 
should occur mostly within job functions rather than across job functions, so as to preserve taskspecific human capital.

The formal theoretical model of Jin and Waldman (2016) explains horizontal moves by building on the idea of skill accumulation via job rotation when skills are task-specific. When human capital is task-specific, and when higher-level jobs require knowledge of multiple skills, workers who move horizontally early in their careers acquire a broad portfolio of skills that increases their promotion chances. All of the promotions and horizontal moves in that model, however, are internal, so the model does not speak to prior result 5 . The formal theoretical model of Cassidy et al. (2016) explains both external and internal horizontal mobility, but that model is devoid of task-specific human capital, and all separations occur exogenously.

In addition to confirming prior result 5 in a broader sample, we refine it further by distinguishing between horizontal moves that change job function and those that do not. A challenge in the empirical internal-versus-external hiring literature is distinguishing external horizontal moves from external promotions (or demotions), because of the difficulties associated with defining comparable job hierarchies across firms. Our data allow us to make this distinction and to refine it by distinguishing between external horizontal moves that involve changes in job function and those that do not (thereby preserving task-specific human capital).

\section{Data and Methods}

The data set is a large, linked, employee-employer panel from 1981 to 2014, based on the administrative records of the Confederation of Finnish Industries (EK), which is the central organization of employer associations in Finland. Although EK has member firms from many industries, manufacturing has the greatest representation in the data. EK firms represent over two thirds of Finnish GDP and over 90\% of exports. They are surveyed annually and account for approximately $33 \%$ of Finnish total employment.

Given that a main purpose of the survey is to provide information for collective bargaining, the data contain detailed information on earnings (including performance-related pay) and the individual's job. The response rate is high because all member firms, except for the smallest ones in a few industries, are required to respond. Membership in EK is not compulsory, but it is mainly the smallest firms that are not members. A conservative estimate is that at least $80 \%$ of white-collar manufacturing workers appear in the data.

The EK data allow us to 1) observe workers' prior career histories; 2) construct comparable job functions across firms; 3) identify multiple types of career moves; 4) measure workers' education and experience; and 5) measure wages reliably. There might be gaps in the career (e.g., 
due to spells of unemployment or spells of employment in other sectors). Each surveyed firm has a subset of the same 56 job functions, and all firms receive detailed instructions on how to assign each of the job functions to persons. Therefore, jobs can be classified consistently across firms. The classification allows us to define an employee's prior work history similarly for both internal and external hires.

We restrict the analysis to full-time, white-collar employees, because the job classification system in the blue-collar data is not comparable across firms. We define full-time workers as those whose regular weekly working hours exceed 30. Part-time work for white-collar workers in manufacturing is rare (less than $2 \%$ in 2006). White-collar workers' wages are recorded for the survey month, e.g., October. Information on performance-related pay (including individual and group-level bonuses) refers to the entire year.

We construct work-history variables for each person, starting with about 4.4 million personyear observations. We restrict the analysis to years in which a person enters a job (in any firm). For example, for a worker who is observed for 25 years, we use that entire history to construct the yearly work-history variables. If that worker experienced three job changes (e.g., two internal promotions, and one external horizontal move), we would only use those three observations for that worker in the empirical analysis. We restrict the sample to years 2002-2014 so that we can measure employee performance and cleanly identify job function changes and hierarchical changes. On average, each person appears 1.5 times in the sample, which includes 86,549 person-year observations from 58,897 unique individuals working in 1106 firms.

We exclude employees who enter jobs from outside the data, thereby focusing on workers who have spent their entire careers moving within and across firms in our sample. This is not problematic, because most of the mobility out of EK firms is into other EK firms. Napari (2009) explores this issue by drawing on Statistics Finland's Structure of Earnings data, writing "This data set has been compiled annually since 1995 and it provides information on wage and salary earners in all employer sectors in Finland containing roughly 1,300,000 individuals in 2004. Calculated from the Structure of Earnings data, on average only about $0.9 \%$ of white-collar workers employed in firms affiliated with $\mathrm{EK}$ in year $\mathrm{t}-1$ are observed in non-member firms in year $\mathrm{t}$ during the period 1995-2004. This holds for both genders. Secondly, the corresponding figure for the transitions from the member firms to the public sector is even lower, $0.4 \%$ for male white-collar workers and $0.5 \%$ for female white-collar workers."

\section{Identifying Career Moves}

We identify career moves using job functions, job levels, and firm identifiers. We describe the job function first, treating it separately for the years 1981-2001 and 2002-2014 because of a 
classification change in 2002. The job classification in 2002-2014 is a four-digit code for which: 1) The first three digits describe the job function (e.g., product $R \& D$, process $R \& D$, Information and Communications Technology (ICT) planning, ICT maintenance, finance and investment, accounting, etc.) and 2) the fourth digit describes the hierarchical level (Managerial ${ }^{3}$, Professional ${ }^{4}$, Expert $^{5}$, Clerical $\left.^{6}\right)$.

A four-level job hierarchy cannot provide an exact description of the white-collar portion of the hierarchy in every firm, which highlights a challenge with multi-firm research. A benefit of single-firm studies is that researchers have precise details about the way jobs are organized, which allows identification of what constitutes a promotion from the perspective of the organization's workers. That level of detail is lost in a multi-firm sample. In particular, imposing a hierarchy of only four levels on every firm in the sample might cause us to overstate the number of lateral moves and understate the number of promotions, particularly in the top (managerial) job level.

Nonetheless, a four-level hierarchy corresponds well to the typical firm and to previous work.

For example, Baker et al. (1994) infer an eight-level job hierarchy in the white-collar portion of the firm they study, but the lowest four levels contain $97.5 \%$ of the workers. The authors write, "in this sense the [white collar portion of the] firm has four significant levels". Only the first four levels of those data are used in DeVaro and Waldman (2012), because the highest four levels are so sparse that they disappear after selecting on a few key variables. Similarly, Bidwell and Mollick (2015) estimate models with three job-level dummies, with a fourth as the reference group.

Moreover, Frederiksen et al. (2017) revisit some of the well-known single-firm personnel data sets from the literature, finding that all data sets use job hierarchies with five to six levels, and in six out of seven firms the three thickest levels contain more than $90 \%$ of the workers. Thus, the four-level hierarchy should offer a good approximation of the hierarchies of our sampled firms. Moreover, the

\footnotetext{
${ }^{3}$ Managers plan, direct, coordinate and evaluate the overall activities of enterprises or of organizational units within them. Tasks performed by managers usually include: planning and directing daily operations; investment, operational and recruitment decisions; responsibility for personnel development, responsibility of performance.

${ }^{4}$ Professionals increase the existing stock of knowledge and apply scientific concepts and theories. Tasks performed by professionals usually include: conducting research and development, developing operational methods, demanding planning tasks, managerial duties. Supervision of other workers may be included.

${ }^{5}$ Experts perform mostly technical and related tasks connected with research and the application of scientific concepts and operational methods. Tasks performed by experts usually include: undertaking and carrying out technical work connected with research; planning of production, logistics and maintenance; initiating and carrying out various technical services related to trade, finance, and administration. Supervision of other workers may be included.

${ }^{6}$ Clerical support workers record, organize, store, compute and retrieve information and perform a number of clerical duties. Tasks performed by clerical support workers usually include typing, operating word processors and other office machines; entering data into computers; carrying out secretarial duties; recording and computing numerical data; keeping records filing documents; carrying out duties in connection with mail services; preparing and checking material for printing; performing money-handling operations; dealing with travel arrangements; supplying information requested by clients and making appointments; operating a telephone switchboard. Supervision of other workers may be included.
} 
sampled firms are provided detailed information (see the preceding four footnotes) to ensure that jobs are correctly classified into levels consistently across firms.

Each of 18 families of job functions has about three functions, on average, for a total of 56. The 18 families are: 1) Business management and development, 2) Research and development, 3) Quality control, 4) Manufacturing, 5) Construction, 6) Transport and storage, 7) Information and communications technology, 8) Maintenance and repair, 9) Purchases, 10) Sales and marketing, 11) Communication, 12) Law, insurance and tax affairs, 13) Environmental management, 14) Financial management, 15) Administration services, 16) Personnel management, 17) Occupational health care and security, and 18) Corporate security. The largest family is Research and Development, which contains three functions: Research, Product R\&D, and Process R\&D. Financial management has: Finance and investments; Accounting; Treasury, invoicing, debt collection; Internal auditing; and General financial administration. Many functions, but not all, exist in all four hierarchical levels.

In the years 1981-2001 there are 75 different job functions, but the data do not contain a code for the hierarchical level. We use the hierarchical classification of Kauhanen and Napari (2012), which applies the job descriptions of the 75 job functions to sort them into six hierarchical levels. The construction of career histories related to the job function for the years 1981-2001 follows that classification. Due to the 2002 change in the classification, we cannot identify changes in job functions or hierarchical levels between 2001 and 2002. We exclude 2002 from the analysis because we cannot identify changes in job functions and levels confidently for that year.

There are six ways to enter a job in our data: 1) internal horizontal transfer, 2) external horizontal transfer, 3 ) internal promotion, 4) external promotion, 5) internal demotion, 6) external demotion. A seventh way is to enter the data for the first time. These workers are not considered, because information about their prior career is unobserved.

We define promotions as transitions from lower to higher hierarchical levels. This definition is consistent with the definition of promotions in theoretical studies of careers, and it lacks the problems associated with self-reported promotions (Pergamit and Veum 1999). We define demotions similarly. Horizontal transfers (both internal and external) are defined as job changes in which the hierarchical level does not change. Internal horizontal transfers, by definition, involve a change in job function (because, given that the hierarchical level does not change, the only way to detect an internal transfer at all is if the job function changes). In contrast, external horizontal transfers may or may not involve a change in job function (because, even with the hierarchical level and job functions remaining fixed, a transition can be detected given that a firm change occurs). In most of the analysis we aggregate these two cases for external transfers (i.e., those that involve a change in job function and those that do not) to present results compactly. 
Table 1 displays the year-to-year transition matrix, including stayers. Fifteen percent of workers who stayed in their current job in a given year experience some type of transition in the following year. Our analysis focuses on those transitions. The transition matrix reveals that demotions are rare, but they tend to occur the year immediately after a promotion (particularly an external one). Although some of these moves might represent misclassifications, the pattern suggests quick corrections of mistaken promotion decisions, particularly external ones.

\section{Empirical Model of Job Transitions}

We estimate a multinomial logit model in which the values of the dependent variable correspond to the six ways $(j=0,1, \ldots, 5)$ to enter a job. Because the six probabilities $P(y=j \mid \mathbf{x})=\exp \left(\mathbf{x} \boldsymbol{\beta}_{j}\right) /\left[1+\sum_{h=1}^{5} \exp \left(\mathbf{x} \boldsymbol{\beta}_{h}\right)\right]$ sum to unity, we estimate only five parameter vectors, assigning internal promotions to the base category, i.e., $\boldsymbol{\beta}_{0}=\mathbf{0}$. The log-odds ratio between category $j$ and the base category is linear, i.e., $\log \left(\frac{P(y=j \mid \mathbf{x})}{P(y=0 \mid \mathbf{x})}\right)=\mathbf{x} \boldsymbol{\beta}_{j}$ for $j=1,2, \ldots, 5$, so $\boldsymbol{\beta}_{j}$ reveals how a change in $x_{x}$ affects the log-odds between category $j$ and the base category. This interpretation of the parameters facilitates comparing the individual and job characteristics of, e.g., external horizontal transfers to those who are internally promoted. The magnitude of the parameters can be assessed using $\beta_{i j}=\frac{\frac{\partial\left(\frac{P(y=j \mid \mathbf{x})}{P(y=0 \mid \mathbf{x})}\right)}{\partial x_{i j}}}{\frac{P(y=j \mid \mathbf{x})}{P(y=0 \mid \mathbf{x})}}$.

We use the multinomial logit model for descriptive purposes to summarize the data; the results do not necessarily have causal interpretations. We measure all individual-level explanatory variables in year $t$, and the job characteristics are measured in year $t+1$. This timing structure allows measurement of the individual-level variables before the transitions, consistent with the focus on the characteristics of the destination job (as opposed to the source job) and, in particular, whether it is growing or not.

\section{Predictors}

Workers' human capital is measured by years of education (and its square), potential experience (five categories), and firm tenure (five categories). Education and experience have been 
used in previous studies on external and internal hiring, but firm tenure has not. ${ }^{7}$ Prior work history is measured by the number of job functions, job levels, firms, promotions, and demotions to date; years at the current job function; and years at the current level. Table 2 displays descriptive statistics for the preceding variables.

We infer a measure of the employee's performance in the previous job from the amount of performance-related pay received, following DeVaro and Kauhanen (2016) and Cassidy et al. (2016). To start, we estimate a regression in which the dependent variable is the log of the performance-related pay that worker $i$ receives in year $t+1$, and the independent variables (including job function dummies, job level dummies, year dummies, and industry dummies) are measured in year $t$. We lead the dependent variable because payments for year-t performance are typically made in year $t+1$. We then use the regression residuals as measures of worker performance. Thus, we measure each worker's performance by how much performance-related pay the worker received compared to other workers in the same job function, same job level, and same industry, in a given year. Firm changers may separate before receipt of performance-related pay, which poses a challenge to their performance measurement. Following Cassidy et al. (2016) we address this issue by using lagged values of performance-related pay for workers who have just switched firms and who have received zero performance-related pay.

A natural question is whether this approach measures true variation in worker performance. DeVaro and Kauhanen (2016) and Cassidy et al. (2016) show that this performance measure matches all empirical regularities of subjective performance measures identified in the literature. Frederiksen et al. (2017) compare subjective performance evaluations across several firms in multiple countries and find three consistent patterns: 1) strong autocorrelation that declines with longer lags; 2) positive correlation with promotions and wages; and 3) negative correlation with demotions and firm separations. In addition, Medoff and Abraham $(1980,1981)$ and DeVaro and Waldman (2012) find a positive correlation between performance and wage growth. The present performance measure matches all of these findings.

A potential concern is that the performance measure may conflate individual and organizational performance. Performance pay in many organizations depends both on individual performance and on overall business performance. If the business does poorly, no one receives a bonus. This might partly account for low performers being more willing to leave their firms - they could just be deserting a firm that is unable to pay the bonus due to poor performance. To address this issue, we recomputed the performance measure by including firm dummies on the regression's

\footnotetext{
${ }^{7}$ However, firm tenure has been used in the analysis of post-hire performance, to investigate whether the performance trajectories of internal and external hires converge or diverge over time.
} 
right-hand side. The results differ only slightly when this alternative performance measure is used, because person effects dominate the variance of the performance measure. An ANOVA analysis (available upon request) of the performance measures illustrates this.

In addition to the individual-level variables, we consider job characteristics, with a distinction between "managerial and professional" jobs (higher in the hierarchy) and "expert and clerical" jobs (lower in the hierarchy). We construct three indicators to distinguish among shrinking, stable (omitted category), and growing jobs. Growing, shrinking, and stable jobs are defined using indictors for whether firm/job-level/job-function cells increase, decrease, or remain unchanged between years $t-1$ and $t$. Firm size has seven categories. Other variables included in the analysis are dummies for job function (18 categories), industry (53 categories), and year.

\section{Results}

\section{Revisiting Previous Evidence}

Table 3, which reveals the routes by which employers fill open vacancies, displays evidence concerning prior results 1 and 2 . Consistent with prior result 1, 60\% percent of vacancies are filled with an internal hire, versus $40 \%$ with an external hire, suggesting an internal hiring preference. However, the most frequent transitions are external horizontal moves (33\%), followed by internal horizontal moves (27\%) and internal promotions (25\%). Eighty-five percent of vacancies are filled via one of these three types of transitions. To focus the analysis, we limit the subsequent discussion of results to these three most common types of transitions.

Consistent with prior result 2, the prevalence of internal promotion increases at higher ranks. For managers and professionals it is $36 \%$ and is the most frequent way to enter a job, whereas for clerical and expert workers it is only 12\%. External horizontal moves are more common for lowerlevel jobs (38\%) than for higher-level ones (29\%). Our result concerning the prevalence of lateral moves (particularly external ones) relative to internal promotions is likely understated due to our focus on white-collar workers, who have relatively high representation in high-level jobs, where internal promotion is more common. Relative to clerical and expert jobs, the higher-level managerial and professional jobs are less likely to be filled by external or internal horizontal hiring than by internal promotion. This result accords with earlier evidence that internal hiring is more common at higher ranks (e.g. Baker et al. 1994, Lazear and Oyer 2004).

Table 4's multinomial logit estimation results show how internal and external horizontal hires compare with internally-promoted employees (Panel A), and how job and firm characteristics 
affect how a job is filled (Panel B). ${ }^{8}$ Consistent with prior results 3 and 4, external horizontal hires are more educated than internally-promoted employees, given that the coefficient on the quadratic education variable is both positive and statistically significant at conventional levels. The result accords with prior evidence (e.g. Baker et al. 1994, Bidwell 2011), though it is documented here in the presence of more detailed proxies for worker performance than have been previously considered.

Column 1 of Table 4 also reveals that work experience is longer for external horizontal hires than for internally-promoted workers. The longer the work experience is, the higher is the log-odds ratio between external horizontal transfer and internal promotion. For example, for those with 16-25 years of work experience the log-odds ratio is 1.7 times higher compared to those with experience up to one year. The result that external hires have a longer work experience than internallypromoted workers has been found previously (Baker et al. 1994, Bidwell 2011, Kauhanen and Napari 2012).

Table 3 reports evidence concerning prior result 5. Consistent with Bidwell and Mollick (2015), the most common type of external move is horizontal. Horizontal transfers account for $83 \%$ of all external moves, $86 \%$ of external moves for lower-level jobs, and $80 \%$ of moves for higherlevel jobs. External promotions are infrequent (4\%), which implies that the external competition faced by internal workers who might get promoted is not from peers at the same job level but rather from external workers one job level up. External demotions are rare. However, in contrast to the evidence from the firm investigated in Baker et al. (1994), internal demotions are not rare and account for nearly $9 \%$ of transitions (or more than $11 \%$ if external demotions are included). Other studies, such as Dohmen et al. (2004) and Belzil and Bognanno (2008) show higher levels of demotions than Baker et al. (1994). In our data, demotions are more common in lower-level jobs than in higher-level ones.

\section{New Evidence}

Table 3 shows that external horizontal transfers are typically hired to the same job function that they held in the previous firm. Only in $15 \%$ of the cases does the job function change. This result, together with the fact that external horizontal moves are the most common way to hire externally, means that external hires typically originate from the same job in the previous firm. One

\footnotetext{
${ }^{8}$ We only report estimates for internal and external horizontal transfers; both should be interpreted relative to the base category (internal promotions). The online appendix (Table A1) reports the complete set of multinomial logit results for all six ways to fill a vacancy. Using "internal promotions" as the baseline means that discussions of results that compare external and internal horizontal moves must also reference internal promotions, because the results for both types of horizontal moves are measured relative to internal promotions.
} 
interpretation is that firms "play it safe" by hiring outsiders only to jobs that they held previously. External horizontal movers that remain in the same job function retain their occupation-specific or task-specific capital (Kambourov and Manovskii 2009, Gathmann and Schönberg 2010) and the hiring firm may infer the productivity of the hires more accurately compared to the situation where the job function changes.

Column 2 of Table 4 reveals that internal horizontal hires are more educated than internallypromoted workers, given that the coefficient on the quadratic education variable is positive and statistically significant at conventional levels. Work experience is also revealed to be longer for internal horizontal hires than for internally-promoted workers. The longer the work experience is, the higher is the log-odds ratio between internal horizontal transfers and internal promotion. For example, for those with 16-25 years of work experience the log-odds ratio is 1.7 times higher compared to those with experience up to one year. These results concerning internal horizontal hires are new, though as noted in the preceding subsection, they mirror the (previously known) results for external horizontal moves. The likely reason for these results is that internal horizontal movers originate at a higher job level than externally promoted workers. Therefore, conditional on having reached that (pre-transition) job level, internal horizontal transfers can be expected to have higher levels of education and experience. The fact that higher job levels are associated with higher levels of education has been shown theoretically (Bernhardt 1995, DeVaro and Waldman 2012) and empirically (DeVaro and Waldman 2012, Cassidy et al. 2016), and similar logic applies to experience.

Table 4 reveals that the coefficient on "years at job function so far" is positive for external horizontal transfers (column 1) and negative for internal horizontal transfers (column 2). This suggests that, for a worker who is about to experience a job change, the more time that the worker has spent in his or her current job function, the more likely it is that the subsequent job change will be an external horizontal move rather than an internal promotion. Similarly, for that same worker, the more time that has been spent in the current job function, the less likely it is that the subsequent job change will be an internal horizontal move rather than an internal promotion. As Table 3 shows, the external hires tend to keep their original job function after switching firms.

There is also persistence in switching firms. Table 4's column 1 shows that external horizontal hires have had more prior employers (i.e., the log-odds ratio between external horizontal transfer and internal promotion is 0.18 higher for one more prior employer). However, Table 4's column 2 shows that employees who make an internal horizontal move or are internally promoted do not differ in the number of prior employers. By "number of prior employers" we mean before an 
external transition occurs, so that the comparison between internally promoted and externally recruited workers is apples-to-apples.

Next we consider three results on the prior career success of internal and external candidates. These results show that even though the external hires have better observable indicators of ability, they have not performed as well as internally promoted workers based on ability indicators that the hiring firm may not fully observe.

First, both internal and external lateral hires' prior career success, as measured by the number of prior promotions and number of prior demotions, is better: they have had more promotions and fewer demotions before moving. For example, the log-odds ratio between internal horizontal hires (external horizontal hires) and internally-promoted employees is 1.01 (0.94) higher for those with one prior promotion compared to employees without prior promotions. Similarly, the log-odds ratio between internal horizontal hires (external horizontal hires) and internally-promoted employees is 0.67 (0.87) lower for those with one prior demotion compared to employees without prior demotions. These numbers show that internally-promoted and internally/externally horizontally transferred employees differ significantly in their work histories, with the latter group having better observable indicators of ability. However, if employees start their careers from the same level, it is natural that employees hired from the same level, internally or externally, have had at least one more promotion than employees promoted from a level below. This highlights the fact that external hires typically come from the same hierarchical level in the previous firm.

Second, compared to horizontal movers, internally-promoted employees have higher performance measures just before the transfer. More precisely, the log-odds ratio between internal (external) horizontal transfers and internal promotion decreases by $0.43(0.97)$ for a one-unit change in performance. The estimates also show that in the preceding year, internal (external) horizontal hires performed better than internally-promoted employees (i.e., the log-odds ratio between internal (external) horizontal transfer and internal promotion increases by $0.17(0.19)$ for a one-unit change in the previous year's performance). Comparison of the coefficients of performance in year $\mathrm{t}$ and $\mathrm{t}-1$ implies that, the employees who get internally promoted have increased their performance compared to the performance of employees who are internally horizontally transferred.

Third, another way to assess prior career success is to compare wages relative to other workers in the same job-function/level/firm/year-cell. As noted in footnote 8 , when they are observable to competing employers, workers' current wages can be signals of ability (Bernhardt and Scoones 1993). Internally-promoted workers have higher wages and higher wage growth compared to their peers. 
Relative to jobs that are growing, those that are stable or shrinking are associated with a lower probability of external horizontal hiring than internal promotion. One possible explanation is simply that when a job is shrinking, the supply of internal candidates that could potentially fill those positions is relatively larger, which reduces the relative benefit of external hiring. Alternatively, the result can be understood in light of theories showing that external hiring decreases incumbent workers' incentives (Chan 1996). The incentive considerations are less relevant when the job's employment is increasing, because then external hiring decreases the promotion probability to a smaller extent than would occur otherwise.

The results also show that when a position is filled internally, the employment growth in the destination job does not differ between jobs that are filled via promotion or horizontal transfer.

\section{Sensitivity Analysis}

The six different mobility types are determined by whether an employee switches firms and/or job levels; they do not distinguish between switching and not switching job function. To see whether employee (as well as job and firm) characteristics differ between employees who move within job functions and those who move across job functions, we estimated the model distinguishing between mobility within and across job functions. ${ }^{9}$ The estimation results are similar to the baseline results, irrespective of whether an employee switches job function or not.

Table 4 shows that firm size is associated with hiring channels. In an investigation of whether the estimation results differ when the sample is restricted to hiring firms of a certain size, as measured by the number of employees, again, the estimation results are similar to the main results. As an alternative measure for job performance, we used levels of performance-related pay instead of logs and did not replace the zeros by lagged values for the firm changers. The results concerning job performance are qualitatively similar to Table 4.

\section{Discussion and Conclusion}

Much of the internal-versus-external hiring literature is based on narrow, often single-firm, samples. Using a large, linked, employer-employee matched panel data set from Finland, we introduce new stylized facts into that literature and re-evaluate the following empirical results:

\footnotetext{
${ }^{9}$ The eleven different mobility types in this case are: internal horizontal transfer, external horizontal transfer (with and without job-function change), internal promotion (with and without job-function change), external promotion (with and without job-function change), internal demotion (with and without job-function change), and external demotion (with and without job-function change).
} 
1) firms have a preference for internal promotion, as opposed to external recruitment (Baker et al. 1994, Lazear and Oyer 2004, Kauhanen and Napari 2012, DeVaro and Morita 2013, Bidwell and Mollick 2015);

2) that preference is strongest at the top of the job hierarchy (Royal and Althauser 2003, Audas et al. 2004, Lazear and Oyer 2004, Kauhanen and Napari 2012);

3) external hires have higher education levels than internally-promoted workers (Baker et al. 1994, Bidwell 2011, Kauhanen and Napari 2012);

4) external hires have higher levels of experience than internally-promoted workers (Baker et al. 1994, Bidwell 2011, Kauhanen and Napari 2012);

5) most external moves are horizontal rather than vertical (Bidwell and Mollick 2015).

Prior result 5 is of particular interest. Bidwell and Mollick (2015) find that the primary source of external mobility is horizontal moves and that these external horizontal moves are an important means of changing job functions. Although our results are consistent with those facts, we uncover the new result that most external horizontal moves occur within job functions.

In our view, the evidence on the importance of (particularly external) horizontal moves calls for increased research attention to that subject, within a hierarchical mobility literature that is dominated by promotion models. The evidence also has implications for tournament theory. That literature requires identifying the relevant pool of competitors that each worker faces in promotion contests. Our results suggest that internal workers at a given job level face their greatest external competition from workers not at the same job level but at the next level up. That insight has been difficult to extract from the prior literature, because most studies cannot distinguish the job levels from which external hires originate. The insight also provides a more obvious explanation than earlier ones for the common finding that external hires are more educated and experienced than internally-promoted workers.

The new result that most external horizontal moves occur within job functions, when combined with growing evidence from labor economics on the importance of task-specific (as opposed to firm-specific) human capital, suggests that external horizontal movers should not suffer a productivity loss when switching firms. This helps to explain earlier findings that external horizontal moves are associated with large wage increases - which are difficult to reconcile with big productivity drops arising from the loss of firm-specific human capital. Bidwell and Keller (2014) find no effect of firm-specific skills, which complements our conclusions that task-specific or job-specific skills are more relevant than firm-specific skills.

A corollary of most external moves being horizontal is that relatively few external moves are promotions. Promotions, when they occur, are more likely to be internal. The notion of 
boundaryless careers (Arthur and Rousseau 2001) - as opposed to organizational careers - is that the evolution of workers' careers is not contained within the boundaries of an organization and often involves external mobility. Our results, like those in Bidwell and Mollick (2015), can be interpreted as a counterpoint to the boundaryless career argument, in the sense that we find significant differences between internal and external moves. In particular, promotions are more likely to be internal than external, at all ranks.

Our confirmation of prior results 3 and 4 is interesting both because the results hold in a broad, multi-firm sample and because the information on work histories (even for external hires) has allowed us to estimate more comprehensive empirical specifications than have been previously considered. Moreover, we control for proxies for worker performance that capture, at least partially, components of worker ability that are often not fully observed by researchers and potential employers. It is interesting that the standard, observable markers of ability (like education and work experience) continue to be relevant even in the presence of controls for prior work history and performance. A new result is that while external hires are superior to internally-promoted workers on observable dimensions of ability like education and experience, they appear worse on the unobserved dimensions of ability. This result is consistent with internally-promoted workers being drawn from the right tail of the within-job-level performance distribution, whereas external horizontal movers are drawn from other parts of the within-job-level performance distribution.

We have shown that job entrants' job histories - perhaps the most important signal recruiters have about external job candidates' characteristics - vary considerably according to whether the entrant is an internal or external hire. In addition to our evidence supporting prior results 3 and 4, we find that, compared to internally-promoted employees, external horizontal hires have longer jobfunction tenures, more prior promotions, and fewer demotions. However, external horizontal transfers have poorer performance in their job prior to the transition. This result is consistent with internally-promoted workers being concentrated in the right tail of the within-job-level performance distribution, to a greater extent than external (lateral) hires.

The work histories of internal horizontal hires are rather similar to the work histories of external horizontal hires. When the horizontal transfers are internal the job function always changes, whereas when they are external it rarely changes. Moreover, internal horizontal hires tend to occur after a relatively short tenure at the previous job function. Thus, internal horizontal transfers seem quite different in nature, perhaps targeted at providing diverse work experience and, hence, preparing for a future promotion.

Our findings suggest a need for further research on the relationship between job history and hiring decisions. The questions of how (1) job vacancies are created and filled, (2) how employees 
select to the external job market, and (3) how employers make recruitment decisions are still largely unexplored. Also outside the scope of the current project is how entrants' job paths and other job market outcomes, such as wages, evolve after entry into the job.

Our results can probably be generalized outside of Finland, both because there is nothing particularly idiosyncratic about Finland's labor market that should affect these results, and because results from earlier work using these data have aligned with research from other countries. For example, Kauhanen and Napari (2012) use these data to replicate the findings from the American personnel data used in Baker et al. (1994), and DeVaro and Kauhanen (2016) use these data to replicate various results from classic tournament theory that were found in data from other countries, including British personnel data (Audas et al. 2004) and a panel of American executives (Bognanno 2001). Although we follow most of the literature in focusing on the white-collar portion of the hierarchy, the extent to which those results generalize to the blue-collar portion is unclear and should be investigated in future work. 


\section{REFERENCES}

Agrawal, Anup, Charles R. Knoeber and Theofanis Tsoulouhas. 2006. Are Outsiders Handicapped in Ceo Successions? Journal of Corporate Finance. 12(3):619-644.

Arthur, Michael Bernard and Denise M Rousseau. 2001. The Boundaryless Career: A New Employment Principle for a New Organizational Era. New York, NY: Oxford University Press.

Audas, Rick, Tim Barmby and John Treble. 2004. Luck, Effort, and Reward in an Organizational Hierarchy. Journal of Labor Economics. 22(2):379-395.

Baker, George, Michael Gibbs and Bengt Holmström. 1994. The Internal Economics of the Firm: Evidence from Personnel Data. Quarterly Journal of Economics. 109(4):881-919.

Baker, George and Bengt Holmström. 1995. Internal Labor Markets: Too Many Theories, Too Few Facts. American Economic Review. 85(2):255-259.

Bayo-Moriones, Alberto and Pedro Ortín-Ángel. 2006. Internal Promotion Versus External Recruitment in Industrial Plants in Spain. Industrial \& Labor Relations Review. 59(3):451470.

Belzil, Christian and Michael Bognanno. 2008. Promotions, Demotions, Halo Effects, and the Earnings Dynamics of American Executives. Journal of Labor Economics. 26(2):287-310.

Bernhardt, Dan. 1995. Strategic Promotion and Compensation. Review of Economic Studies. 62(2):315-339.

Bernhardt, Dan and David Scoones. 1993. Promotion, Turnover, and Preemptive Wage Offers. American Economic Review. 83(4):771-791.

Bidwell, Matthew. 2011. Paying More to Get Less: The Effects of External Hiring Versus Internal Mobility. Administrative Science Quarterly. 56(3):369-407.

Bidwell, Matthew and J. R. Keller. 2014. Within or Without? How Firms Combine Internal and External Labor Markets to Fill Jobs. Academy of Management Journal. 57(4):1035-1055.

Bidwell, Matthew and Ethan Mollick. 2015. Shifts and Ladders: Comparing the Role of Internal and External Mobility in Managerial Careers. Organization Science. 26(6):1629-1645.

Bognanno, Michael L. 2001. Corporate Tournaments. Journal of Labor Economics. 19(2):290-315.

Cassidy, Hugh. 2017. Task Variation within Occupations. Industrial Relations. 56(3):393-410

Cassidy, Hugh, Jed DeVaro and Antti Kauhanen. 2016. Promotion Signaling, Gender, and Turnover: New Theory and Evidence. Journal of Economic Behavior \& Organization. 126, Part A(June 2016):140-166.

Chan, William. 1996. External Recruitment Versus Internal Promotion. Journal of Labor Economics. 14(4):555-570.

Chan, William. 2006. External Recruitment and Intrafirm Mobility. Economic Inquiry. 44(1):169184.

DeVaro, Jed, Suman Ghosh and Cindy Zoghi. 2018. Job Characteristics and Labor Market Discrimination in Promotions. Industrial Relations. 57(3):389-434.

DeVaro, Jed and Antti Kauhanen. 2016. An "Opposing Responses" Test of Classic Versus MarketBased Promotion Tournaments. Journal of Labor Economics. 34(3):747-779.

DeVaro, Jed and Hodaka Morita. 2013. Internal Promotion and External Recruitment: A Theoretical and Empirical Analysis. Journal of Labor Economics. 31(2):227-269.

DeVaro, Jed and Michael Waldman. 2012. The Signalling Role of Promotions: Further Theory and Empirical Evidence. Journal of Labor Economics. 30(1):91-147.

Dohmen, Thomas J., Ben Kriechel and Gerard A. Pfann. 2004. Monkey Bars and Ladders: The Importance of Lateral and Vertical Job Mobility in Internal Labor Market Careers. Journal of Population Economics. 17(2):193-228.

Eriksson, Tor and Jaime Ortega. 2006. The Adoption of Job Rotation: Testing the Theories. ILR Review. 59(4):653-666. 
Fan, Xiaodong and Jed DeVaro. 2018. Does Job Hopping Help or Hinder Careers?: The Signaling Role of Work History. California State University, East Bay,.

Frederiksen, Anders, Timothy Halliday and Alexander K Koch. 2015. Within-and Cross-Firm Mobility and Earnings Growth. Industrial and Labor Relations Review. 69(2):320-353.

Frederiksen, Anders and Takao Kato. 2018. Human Capital and Career Success: Evidence from Linked Employer-Employee Data. Economic Journal. 128(613):1952-1982.

Frederiksen, Anders, Fabian Lange and Ben Kriechel. 2017. Subjective Performance Evaluations and Employee Careers. Journal of Economic Behavior \& Organization. 134(February 2017):408-429.

Gathmann, Christina and Uta Schönberg. 2010. How General Is Human Capital? A Task-Based Approach. Journal of Labor Economics. 28(1):1-49.

Ghosh, Suman and Michael Waldman. 2010. Standard Promotion Practices Versus up-or-out Contracts. RAND Journal of Economics. 41(2):301-325.

Gibbons, Robert and Michael Waldman. 2004. Task-Specific Human Capital. American Economic Review. 94(2):203-207.

Gibbons, Robert and Michael Waldman. 2006. Enriching a Theory of Wage and Promotion Dynamics inside Firms. Journal of Labor Economics. 24(1):59-107.

Greenwald, Bruce C. 1986. Adverse Selection in the Labour Market. Review of Economic Studies. 53(3):325-347.

Hamermesh, Daniel S. 2007. Viewpoint: Replication in Economics. Canadian Journal of Economics. 40(3):715-733.

Jacoby, Sanford M. 2005. The Embedded Corporation. Princeton, NJ: Princeton University Press.

Jin, Xin and Michael Waldman. 2016. Lateral Moves, Promotions, and Task-Specific Human Capital: Theory and Evidence. Cornell University.

Kambourov, Gueorgui and Iourii Manovskii. 2009. Occupational Specificity of Human Capital. International Economic Review. 50(1):63-115.

Kauhanen, Antti and Sami Napari. 2012. Career and Wage Dynamics: Evidence from Linked Employer-Employee Data. In Solomon W. Polachek and Konstantinos Tatsiramos. Research in Labor Economics, pp 35-76: Emerald Group Publishing Limited.

Ke, Rongzhu, Jin Li and Michael Powell. 2018. Managing Careers in Organizations. Journal of Labor Economics. 36(1):197-252.

Lazear, Edward P. and Paul Oyer. 2004. Internal and External Labor Markets: A Personnel Economics Approach. Labour Economics. 11(5):527-554.

Lazear, Edward P. and Sherwin Rosen. 1981. Rank-Order Tournaments as Optimum Labor Contracts. Journal of Political Economy. 89(5):841-864.

Malcomson, James M. 1984. Work Incentives, Hierarchy, and Internal Labor Markets. Journal of Political Economy. 92(3):486-507.

Medoff, James L. and Katharine G. Abraham. 1980. Experience, Performance, and Earnings. Quarterly Journal of Economics. 95(4):703-736.

Medoff, James L. and Katharine G. Abraham. 1981. Are Those Paid More Really More Productive? The Case of Experience. Journal of human resources. 16(2):186-216.

Napari, Sami. 2009. Gender Differences in Early-Career Wage Growth. Labour Economics. 16(2):140-148.

Ortega, Jaime. 2001. Job Rotation as a Learning Mechanism. Management Science. 47(10):13611370.

Pergamit, Michael R. and Jonathan R. Veum. 1999. What Is a Promotion? Industrial and Labor Relations Review. 52(4):581-601.

Prendergast, Canice. 1993. The Role of Promotion in Inducing Specific Human Capital Acquisition. Quarterly Journal of Economics. 108(2):525. 
Royal, Carol and Robert P Althauser. 2003. The Labor Markets of Knowledge Workers: Investment Bankers' Careers in the Wake of Corporate Restructuring. Work and Occupations. 30(2):214-233.

Waldman, Michael. 2003. Ex Ante Versus Ex Post Optimal Promotion Rules: The Case of Internal Promotion. Economic Inquiry. 41(1):27-41.

Waldman, Michael. 2013. Theory and Evidence in Internal Labor Markets. In Robert Gibbons and John Roberts. The Handbook of Organizational Economics. Princeton, NJ: Princeton University Press.

Zábojník, Ján and Dan Bernhardt. 2001. Corporate Tournaments, Human Capital Acquisition, and the Firm Size-Wage Relation. Review of Economic Studies. 68(3):693-716. 
Table 1: One-Year Transition Matrix

$\mathbf{t}+\mathbf{1}$

\begin{tabular}{|c|c|c|c|c|c|c|c|}
\hline $\begin{array}{l}\text { Internal } \\
\text { horizontal } \\
\text { transfer }\end{array}$ & $\begin{array}{l}\text { External } \\
\text { horizontal } \\
\text { transfer }\end{array}$ & $\begin{array}{c}\text { Internal } \\
\text { promotion }\end{array}$ & $\begin{array}{l}\text { External } \\
\text { promotion }\end{array}$ & $\begin{array}{c}\text { Internal } \\
\text { demotion }\end{array}$ & $\begin{array}{l}\text { External } \\
\text { demotion }\end{array}$ & Stayer & Total \\
\hline 9.95 & 7.53 & 5.98 & 0.74 & 1.89 & 0.46 & 73.46 & \\
\hline 3.57 & 8.24 & 3.41 & 0.71 & 1.29 & 0.42 & 82.37 & \\
\hline 7.77 & 4.86 & 1.11 & 0.25 & 4.88 & 1 & 80.13 & \\
\hline 4.81 & 4 & 1.18 & 0.28 & 6.44 & 1.08 & 82.21 & \\
\hline 5.6 & 4.4 & 13.4 & 1.59 & 0.74 & 0.26 & 74.01 & \\
\hline 3.23 & 3.84 & 10.43 & 2.01 & 0.61 & 0.06 & 79.82 & \\
\hline 3.62 & 4.97 & 3.69 & 0.67 & 1.19 & 0.4 & 85.46 & \\
\hline 4.13 & 5.21 & 3.84 & 0.68 & 1.4 & 0.43 & 84.32 & \\
\hline
\end{tabular}


Table 2: Descriptive Statistics

\begin{tabular}{|c|c|c|c|c|}
\hline Variable & Mean & $\begin{array}{l}\text { Standard } \\
\text { deviation }\end{array}$ & Min & Max \\
\hline Years of education & 15.10 & 2.84 & 9 & 25 \\
\hline Experience up to one year & 0.04 & 0.19 & 0 & 1 \\
\hline $2-5$ years & 0.11 & 0.31 & 0 & 1 \\
\hline $6-15$ years & 0.36 & 0.48 & 0 & 1 \\
\hline $16-25$ years & 0.29 & 0.46 & 0 & 1 \\
\hline More than 25 years & 0.20 & 0.40 & 0 & 1 \\
\hline Tenure up to one year & 0.10 & 0.30 & 0 & 1 \\
\hline $2-5$ years & 0.29 & 0.45 & 0 & 1 \\
\hline $6-10$ years & 0.21 & 0.41 & 0 & 1 \\
\hline $11-15$ years & 0.14 & 0.35 & 0 & 1 \\
\hline More than 15 years & 0.25 & 0.43 & 0 & 1 \\
\hline Female & 0.31 & 0.46 & 0 & 1 \\
\hline Performance & 0.07 & 0.86 & -7.82 & 4.09 \\
\hline Number of job functions to date & 2.22 & 1.39 & 1 & 12 \\
\hline Number of employers to date & 1.41 & 0.72 & 1 & 9 \\
\hline Years at job function so far & 6.38 & 5.55 & 1 & 33 \\
\hline Years at level so far & 7.05 & 5.85 & 1 & 33 \\
\hline No prior promotions & 0.52 & 0.50 & 0 & 1 \\
\hline 1 prior promotion & 0.34 & 0.47 & 0 & 1 \\
\hline More than 1 prior promotion & 0.14 & 0.35 & 0 & 1 \\
\hline No prior demotions & 0.77 & 0.42 & 0 & 1 \\
\hline 1 prior demotion & 0.19 & 0.39 & 0 & 1 \\
\hline More than 1 prior demotion & 0.04 & 0.19 & 0 & 1 \\
\hline Relative wage & 0.57 & 4.84 & -68.47 & 54.45 \\
\hline Relative wage growth & -0.04 & 1.80 & -70.82 & 6.00 \\
\hline Labor market entrant & 0.26 & 0.44 & 0 & 1 \\
\hline Clerical and expert jobs & 0.47 & 0.50 & 0 & 1 \\
\hline Managerial and professional jobs & 0.53 & 0.50 & 0 & 1 \\
\hline Growing job & 0.78 & 0.41 & 0 & 1 \\
\hline Stable job & 0.04 & 0.21 & 0 & 1 \\
\hline Shrinking job & 0.17 & 0.38 & 0 & 1 \\
\hline Firm size smaller than 50 & 0.05 & 0.21 & 0 & 1 \\
\hline $50-100$ & 0.04 & 0.20 & 0 & 1 \\
\hline $100-200$ & 0.08 & 0.27 & 0 & 1 \\
\hline $200-500$ & 0.15 & 0.35 & 0 & 1 \\
\hline $500-100$ & 0.12 & 0.32 & 0 & 1 \\
\hline $1000-2000$ & 0.13 & 0.33 & 0 & 1 \\
\hline larger than 2000 & 0.44 & 0.50 & 0 & 1 \\
\hline Business management and development & 0.01 & 0.12 & 0 & 1 \\
\hline Research and development & 0.23 & 0.42 & 0 & 1 \\
\hline Quality control & 0.04 & 0.19 & 0 & 1 \\
\hline Manufacturing & 0.11 & 0.32 & 0 & 1 \\
\hline
\end{tabular}


Construction

Transport and storage

ICT

Maintenance and repair

Purchases

Sales and marketing

Communication

Law, insurance and tax affairs

Environmental management

Financial management

Administration services

Personnel management

Occupational health care and security

Corporate security

\begin{tabular}{llll}
0.06 & 0.24 & 0 & 1 \\
0.04 & 0.19 & 0 & 1 \\
0.13 & 0.34 & 0 & 1 \\
0.04 & 0.19 & 0 & 1 \\
0.04 & 0.21 & 0 & 1 \\
0.17 & 0.38 & 0 & 1 \\
0.01 & 0.09 & 0 & 1 \\
0.00 & 0.06 & 0 & 1 \\
0.00 & 0.05 & 0 & 1 \\
0.05 & 0.22 & 0 & 1 \\
0.03 & 0.17 & 0 & 1 \\
0.03 & 0.16 & 0 & 1 \\
0.00 & 0.06 & 0 & 1 \\
0.00 & 0.06 & 0 & 1 \\
\hline
\end{tabular}

The number of observations is 86,563 for each variable 
Table 3: Routes to a job, \%

\begin{tabular}{lcccr} 
Routes to a job & All & $\begin{array}{c}\text { Clerical } \\
\text { and } \\
\text { Expert }\end{array}$ & $\begin{array}{c}\text { Managerial } \\
\text { and } \\
\text { Professional }\end{array}$ & $\begin{array}{c}\text { Job title } \\
\text { changes } \\
\%\end{array}$ \\
\hline Internal horizontal transfer & 26.8 & 28.3 & 25.5 & 1 \\
External horizontal transfer & 33.2 & 38.2 & 28.8 & 0.15 \\
Internal promotion & 24.5 & 11.9 & 35.7 & 0.33 \\
External promotion & 4.3 & 2.0 & 6.3 & 0.52 \\
Internal demotion & 8.6 & 15.2 & 2.7 & 0.41 \\
External demotion & 2.6 & 4.3 & 1.0 & 0.60 \\
\hline Total & 100 & 100 & 100 & \\
Observations & 86,563 & 40,831 & 45,732 &
\end{tabular}


Table 4: Results from Multinomial Logit: Internal and external horizontal transfers

Panel A: Employee level variables

$\begin{array}{cc}\begin{array}{c}\text { External } \\ \text { horizontal } \\ \text { transfer }\end{array} & \begin{array}{c}\text { Internal } \\ \text { horizontal } \\ \text { transfer }\end{array}\end{array}$

\section{Education}

Years of education

$\begin{array}{cc}-0.03 & -0.02 \\ (-0.56) & (-0.30) \\ 0.01 * * & 0.01 * \\ (2.93) & (2.55)\end{array}$

Work experience

Experience up to one year

$2-5$ years

$\begin{array}{cc}0.48 * * * & 0.47 * * * \\ (5.20) & (6.71) \\ 1.11 * * * & 1.07 * * * \\ (8.95) & (10.32) \\ 1.68 * * * & 1.66 * * * \\ (11.50) & (12.91) \\ 1.84 * * * & 1.85 * * * \\ (11.47) & (12.99) \\ 0.06 & 0.11 * * * \\ (1.71) & (3.56) \\ 0.16 * & -0.06 \\ (2.42) & (-1.51) \\ 0.02 * & -0.04 * * * \\ (2.11) & (-5.80) \\ 0.01 & 0.01 \\ (0.74) & (1.56)\end{array}$

6-15 years

$1.11 * * *$

$07 * * *$

$16-25$ years

$1.68 * * *$

$1.66^{* * *}$

More than 25 years

\section{Firm tenure}

Tenure up to one year

2-5 years

$\begin{array}{cc}-0.14 & -0.25^{*} \\ (-0.66) & (-2.22) \\ -0.31 & -0.26^{*} \\ (-1.34) & (-2.09) \\ -0.10 & -0.08 \\ (-0.41) & (-0.55) \\ -0.44 & -0.20 \\ (-1.49) & (-1.27)\end{array}$

Prior performance

Performance

$-0.97 * * * \quad-0.43 * * *$

Performance t-1

$\begin{array}{cc}(-6.41) & (-5.24) \\ 0.17 & 0.19 * * \\ (1.37) & (2.84)\end{array}$

No prior promotions

1 prior promotion

$0.92^{* * *} \quad 0.96^{* * *}$ 


$\begin{array}{lcc} & (13.46) & (16.47) \\ \text { More than 1 prior promotion } & 1.55^{* * *} & 1.45^{* * *} \\ & (12.71) & (12.03) \\ \text { No prior demotions } & & \\ 1 \text { prior demotion } & -0.77^{* * *} & -0.60^{* * *} \\ & (-11.63) & (-7.44) \\ \text { More than 1 prior demotion } & -1.47^{* * *} & -1.20^{* * *} \\ & (-12.64) & (-8.21)\end{array}$

\section{Other}

Relative wage

$$
-0.09 * * * \quad-0.12 * * *
$$

Relative wage growth

$(-9.08) \quad(-11.11)$

$-0.03 \quad-0.03 * *$

$(-1.69) \quad(-3.13)$

Female

Panel B: Job and firm level variables

\section{Job characteristics}

Clerical and expert jobs

Managerial and professional jobs

$$
\begin{array}{ll}
-2.25 * * * & -2.13 * * * \\
(-24.25) & (-21.81)
\end{array}
$$

Growing job

Stable job

$\begin{array}{cc}-1.10^{* * *} & -0.09 \\ (-7.66) & (-1.17) \\ -1.75^{* * *} & -0.05 \\ (-4.35) & (-0.35)\end{array}$

Firm characteristics

Firm size smaller than 50

\begin{tabular}{lcc}
$51-100$ & 0.17 & 0.06 \\
& $(0.78)$ & $(0.36)$ \\
$101-200$ & -0.20 & 0.03 \\
& $(-0.88)$ & $(0.17)$ \\
$201-500$ & -0.32 & $0.44^{* *}$ \\
$501-1000$ & $(-1.40)$ & $(3.05)$ \\
& 0.41 & $0.73^{* * *}$ \\
$1001-2000$ & $(1.23)$ & $(4.06)$ \\
& -0.75 & 0.20 \\
larger than 2000 & $(-1.91)$ & $(1.03)$ \\
& $-1.04^{* *}$ & $0.44^{* *}$ \\
Industry indicators & $(-2.60)$ & $(2.64)$ \\
Year indicators & Yes & Yes \\
Observations & Yes & Yes \\
\hline Share of all observations $(\%)$ & 86563 & \\
\hline
\end{tabular}


Notes: Estimated coefficients are reported, with t-statistics in parentheses $(* \mathrm{p}<0.05, * * \mathrm{p}<0.01, * * * \mathrm{p}<0.001)$. The baseline category of the dependent variable is Internal promotion. The dependent variable is a transition between year $t$ and $t+1$, and the individual-level variables are measured at year $t$. Relative wage and wage growth are calculated within jobtitle/level/firm/year-cells. The job and firm-level variables refer to the destination job (i.e., they are measured at year $t+1$ ) Growing, shrinking, and stable jobs are indicators for whether employment in the job title/level/firm-cell increases, decreases, or is unchanged between years $t$ and $t+1$. 
Table A1: Results from Multinomial Logit: Full table

\section{Panel A: Employee level variables}

$\begin{array}{lllll}\text { Internal } & \text { External } & \text { External } & \text { Internal } & \text { External } \\ \text { horizontal } & \text { horizontal } & \text { promotion } & \text { demotion } & \text { demotion } \\ \text { transfer } & \text { transfer } & \text { prom }\end{array}$

\section{Education}

Years of education

Years of education ${ }^{2}$

\section{Work experience}

Experience up to one year

2-5 years

6-15 years

$16-25$ years

More than 25 years

Number of job functions to date

Number of employers to date

Years at function so far

Years at level so far

\section{Firm tenure}

Tenure up to one year

2-5 years

6-10 years

11-15 years

More than 15 years

\section{Prior performance}

Performance

Performance t-1

No prior promotions

$\begin{array}{ccccc}-0.02 & -0.03 & 0.07 & 0.16^{*} & 0.16 \\ (-0.30) & (-0.56) & (0.92) & (2.33) & (1.79) \\ 0.01 * & 0.01 * * & -0.00 & 0.01 * * & 0.01 * * \\ (2.55) & (2.93) & (-0.86) & (2.72) & (2.86)\end{array}$

$\begin{array}{ccccc}0.47 * * * & 0.48^{* * *} & 0.00 & 0.52 * * * & 0.66^{* * *} \\ (6.71) & (5.20) & (0.02) & (4.56) & (4.61) \\ 1.07 * * * & 1.11^{* * *} & -0.00 & 1.67 * * * & 1.69 * * * \\ (10.32) & (8.95) & (-0.04) & (12.00) & (10.54) \\ 1.66 * * * & 1.68 * * * & -0.04 & 2.70^{* * *} & 2.41^{* * *} \\ (12.91) & (11.50) & (-0.26) & (15.96) & (12.74) \\ 1.85 * * * & 1.84 * * * & -0.34 * & 3.21 * * * & 2.57 * * * \\ (12.99) & (11.47) & (-2.11) & (17.25) & (12.39) \\ 0.11^{* * *} & 0.06 & -0.03 & 0.07 * & 0.19 * * * \\ (3.56) & (1.71) & (-0.65) & (2.04) & (4.09) \\ -0.06 & 0.16 * & 0.18 * * & 0.08 & 0.21 * * \\ (-1.51) & (2.42) & (3.11) & (1.58) & (3.01) \\ -0.04 * * * & 0.02 * & -0.00 & 0.01 & 0.04 * * * \\ (-5.80) & (2.11) & (-0.29) & (1.13) & (3.35) \\ 0.01 & 0.01 & 0.02 & -0.03 * * * & -0.04 * \\ (1.56) & (0.74) & (1.85) & (-3.47) & (-2.43)\end{array}$

$\begin{array}{ccccc}-0.25 * & -0.14 & -0.12 & -0.19 & -0.11 \\ (-2.22) & (-0.66) & (-0.73) & (-1.66) & (-0.59) \\ -0.26 * & -0.31 & -0.30 & -0.14 & -0.33 \\ (-2.09) & (-1.34) & (-1.56) & (-1.05) & (-1.77) \\ -0.08 & -0.10 & -0.52 * & 0.03 & -0.12 \\ (-0.55) & (-0.41) & (-2.50) & (0.21) & (-0.54) \\ -0.20 & -0.44 & -0.94 * * * & -0.28 & -0.72 * * \\ (-1.27) & (-1.49) & (-3.90) & (-1.65) & (-2.83) \\ & & & & \\ -0.43^{* * *} & -0.97 * * * & -0.77 * * * & -0.95^{* * *} & -1.08^{* * *} \\ (-5.24) & (-6.41) & (-5.47) & (-8.85) & (-7.29) \\ 0.19 * * & 0.17 & 0.29 * * * & 0.17 * & 0.25 * \\ (2.84) & (1.37) & (3.73) & (2.08) & (2.17)\end{array}$




\begin{tabular}{lccccc}
1 prior promotion & $0.96^{* * *}$ & $0.92^{* * *}$ & -0.02 & $1.86^{* * *}$ & $1.80^{* * *}$ \\
& $(16.47)$ & $(13.46)$ & $(-0.26)$ & $(22.38)$ & $(17.31)$ \\
More than 1 prior promotion & $1.45^{* * *}$ & $1.55^{* * *}$ & -0.07 & $3.04 * * *$ & $3.11^{* * *}$ \\
& $(12.03)$ & $(12.71)$ & $(-0.52)$ & $(22.48)$ & $(18.27)$ \\
No prior demotions & & & & & \\
1 prior demotion & $-0.60^{* * *}$ & $-0.77 * * *$ & 0.06 & $-1.19 * * *$ & $-1.30^{* * *}$ \\
& $(-7.44)$ & $(-11.63)$ & $(0.41)$ & $(-10.47)$ & $(-10.61)$ \\
More than 1 prior demotion & $-1.20^{* * *}$ & $-1.47 * * *$ & -0.03 & $-1.99^{* * *}$ & $-2.50^{* * *}$ \\
& $(-8.21)$ & $(-12.64)$ & $(-0.17)$ & $(-11.27)$ & $(-11.75)$ \\
Other & & & & & \\
Relative wage & $-0.12^{* * *}$ & $-0.09 * * *$ & -0.01 & $-0.25^{* * *}$ & $-0.21 * * *$ \\
& $(-11.11)$ & $(-9.08)$ & $(-1.17)$ & $(-18.33)$ & $(-15.43)$ \\
Relative wage growth & $-0.03 * *$ & -0.03 & $-0.03 *$ & -0.03 & $-0.04 *$ \\
& $(-3.13)$ & $(-1.69)$ & $(-2.52)$ & $(-1.55)$ & $(-1.99)$ \\
Female & $-0.64 * * *$ & $-0.61 * * *$ & -0.06 & $-1.12 * * *$ & $-1.04 * * *$ \\
& $(-14.41)$ & $(-12.57)$ & $(-0.77)$ & $(-13.84)$ & $(-11.86)$ \\
\hline
\end{tabular}

Panel B: Job and firm level variables

\section{Job characteristics}

Clerical and expert jobs

Managerial and professional jobs

$\begin{array}{ccccc}-2.13 * * * & -2.25 * * * & 0.24 & -4.55 * * * & -4.41 * * * \\ (-21.81) & (-24.25) & (1.46) & (-31.08) & (-29.28) \\ & & & & \\ -0.09 & -1.10^{* * *} & -0.21 & -0.12 & -0.46 * * * \\ (-1.17) & (-7.66) & (-1.86) & (-1.16) & (-3.35) \\ -0.05 & -1.75 * * * & -1.10 * * & -0.10 & -0.70 * * \\ (-0.35) & (-4.35) & (-2.76) & (-0.77) & (-2.90)\end{array}$

Research and development

Business management and

development

$1.64 * * *$

$0.71 * * *$

$0.59 * *$

$0.99 * * *$

$1.51 * * *$

(7.32)

(3.35)

$0.61 * * *$

$-0.07$

(2.71)

(3.67)

(3.74)

Quality control

(4.11)

$(-0.45)$

0.18

0.35

0.04

Manufacturing

0.11

$-0.06$

(1.05)

(1.83)

$(0.18)$

(0.68)

$(-0.33)$

$-0.09$

0.11

$-0.02$

Construction

$-0.19$

0.30

$(-0.48)$

(0.63)

$(-0.11)$

$(-0.87)$

(1.12)

0.36

$-0.17$

0.03

Transport and storage

$0.43 * *$

$-0.54 * *$

(1.49)

$(-0.58)$

(0.12)

(3.23)

$(-2.58)$

$-0.11$

0.10

$-0.33$

ICT

$0.58 * * *$

$-0.11$

$(-0.35)$

(0.53)

$(-1.38)$

(3.97)

$(-0.50)$

$-0.13$

$-0.14$

0.08

Maintenance and repair

$0.42 *$

$-0.12$

$(-0.68)$

$(-0.75)$

$(0.30)$

(2.26)

$(-0.43)$

0.14

0.36

0.25

Purchases

$0.59^{* * *}$

$-0.20$

$(0.58)$

(1.47)

$(0.59)$

(3.45)

$(-1.22)$

0.02

0.07

0.36

Sales and marketing

$0.57 * * *$

0.15

$(0.09)$

$(0.27)$

(1.50)

(3.99)

(1.06)

0.02

$0.58 * * *$

0.50 *

(0.11)

(3.73)

(2.52) 


\begin{tabular}{|c|c|c|c|c|c|}
\hline Communication & $\begin{array}{c}0.16 \\
(0.66)\end{array}$ & $\begin{array}{c}-0.13 \\
(-0.58)\end{array}$ & $\begin{array}{l}-0.28 \\
(-1.18)\end{array}$ & $\begin{array}{c}0.46 \\
(1.55)\end{array}$ & $\begin{array}{l}0.84^{*} \\
(2.26)\end{array}$ \\
\hline Law, insurance and tax affairs & $\begin{array}{c}-0.39 \\
(-1.52)\end{array}$ & $\begin{array}{l}-0.46^{*} \\
(-2.22)\end{array}$ & $\begin{array}{c}-0.01 \\
(-0.05)\end{array}$ & $\begin{array}{c}-0.29 \\
(-0.74)\end{array}$ & $\begin{array}{c}-0.34 \\
(-0.60)\end{array}$ \\
\hline Environmental management & $\begin{array}{c}1.13^{* * *} \\
(4.22)\end{array}$ & $\begin{array}{c}0.00 \\
(0.01)\end{array}$ & $\begin{array}{c}0.20 \\
(0.50)\end{array}$ & $\begin{array}{c}0.56 \\
(1.46)\end{array}$ & $\begin{array}{c}0.47 \\
(0.85)\end{array}$ \\
\hline Financial management & $\begin{array}{c}0.17 \\
(1.36)\end{array}$ & $\begin{array}{c}-0.03 \\
(-0.16)\end{array}$ & $\begin{array}{l}0.43 * \\
(2.39)\end{array}$ & $\begin{array}{c}0.21 \\
(1.05)\end{array}$ & $\begin{array}{c}0.41 \\
(1.90)\end{array}$ \\
\hline Administration services & $\begin{array}{l}-0.34 * \\
(-2.49)\end{array}$ & $\begin{array}{l}-0.22 \\
(-1.25)\end{array}$ & $\begin{array}{c}0.09 \\
(0.37)\end{array}$ & $\begin{array}{c}0.07 \\
(0.32)\end{array}$ & $\begin{array}{l}-0.07 \\
(-0.30)\end{array}$ \\
\hline Personnel management & $\begin{array}{l}0.30 * \\
(2.26)\end{array}$ & $\begin{array}{l}-0.05 \\
(-0.30)\end{array}$ & $\begin{array}{l}0.45^{*} \\
(2.34)\end{array}$ & $\begin{array}{c}0.09 \\
(0.43)\end{array}$ & $\begin{array}{l}0.63 * * \\
(2.62)\end{array}$ \\
\hline Occupational health care and security & $\begin{array}{c}0.52 \\
(1.68)\end{array}$ & $\begin{array}{c}0.06 \\
(0.16)\end{array}$ & $\begin{array}{c}0.22 \\
(0.59)\end{array}$ & $\begin{array}{c}0.61 \\
(1.42)\end{array}$ & $\begin{array}{c}0.68 \\
(1.42)\end{array}$ \\
\hline Corporate security & $\begin{array}{c}0.61 \\
(1.92)\end{array}$ & $\begin{array}{c}-0.49 \\
(-1.54)\end{array}$ & $\begin{array}{l}-1.01 * \\
(-2.10)\end{array}$ & $\begin{array}{c}0.45 \\
(1.28)\end{array}$ & $\begin{array}{l}-0.07 \\
(-0.12)\end{array}$ \\
\hline $\begin{array}{l}\text { Firm characteristics } \\
\text { Firm size smaller than } 50\end{array}$ & & & & & \\
\hline $51-100$ & $\begin{array}{c}0.06 \\
(0.36)\end{array}$ & $\begin{array}{c}0.17 \\
(0.78)\end{array}$ & $\begin{array}{c}-0.24 \\
(-1.25)\end{array}$ & $\begin{array}{c}0.21 \\
(0.92)\end{array}$ & $\begin{array}{l}-0.10 \\
(-0.45)\end{array}$ \\
\hline $101-200$ & $\begin{array}{c}0.03 \\
(0.17)\end{array}$ & $\begin{array}{l}-0.20 \\
(-0.88)\end{array}$ & $\begin{array}{c}-0.69 * * * \\
(-3.85)\end{array}$ & $\begin{array}{c}-0.13 \\
(-0.67)\end{array}$ & $\begin{array}{l}-0.45^{*} \\
(-2.22)\end{array}$ \\
\hline $201-500$ & $\begin{array}{l}0.44 * * \\
(3.05)\end{array}$ & $\begin{array}{c}-0.32 \\
(-1.40)\end{array}$ & $\begin{array}{c}-0.91^{* * *} \\
(-4.85)\end{array}$ & $\begin{array}{c}0.10 \\
(0.50)\end{array}$ & $\begin{array}{c}-0.74 * * * \\
(-3.74)\end{array}$ \\
\hline $501-1000$ & $\begin{array}{c}0.73 * * * \\
(4.06)\end{array}$ & $\begin{array}{c}0.41 \\
(1.23)\end{array}$ & $\begin{array}{l}-0.74 * * \\
(-2.86)\end{array}$ & $\begin{array}{l}0.56^{*} \\
(2.09)\end{array}$ & $\begin{array}{l}-0.32 \\
(-1.03)\end{array}$ \\
\hline $1001-2000$ & $\begin{array}{c}0.20 \\
(1.03)\end{array}$ & $\begin{array}{l}-0.75 \\
(-1.91)\end{array}$ & $\begin{array}{c}-1.91 * * * \\
(-6.12)\end{array}$ & $\begin{array}{c}0.02 \\
(0.07)\end{array}$ & $\begin{array}{c}-1.76 * * * \\
(-6.19)\end{array}$ \\
\hline larger than 2000 & $\begin{array}{l}0.44 * * \\
(2.64)\end{array}$ & $\begin{array}{l}-1.04 * * \\
(-2.60)\end{array}$ & $\begin{array}{c}-2.10 * * * \\
(-5.96)\end{array}$ & $\begin{array}{l}-0.34 \\
(-1.45)\end{array}$ & $\begin{array}{l}-2.32 * * * \\
(-6.94)\end{array}$ \\
\hline Industry indicators & Yes & Yes & Yes & Yes & Yes \\
\hline Year indicators & Yes & Yes & Yes & Yes & Yes \\
\hline Observations & 86563 & & & & \\
\hline
\end{tabular}

Notes: Estimated coefficients are reported, with t-statistics in parentheses $(* p<0.05, * * p<0.01, * * *$ $\mathrm{p}<0.001)$. The baseline category of the dependent variable is Internal promotion. The dependent variable is a transition between year $t$ and $t+1$, and the individual-level variables are measured at year $t$. Relative wage and wage growth are calculated within job-function/level/firm/year-cells. The job and firm-level variables refer to the destination job (i.e., they are measured at year $t+1$ ). Growing, shrinking, and stable jobs are indicators for whether employment in the job title/level/firm-cell increases, decreases, or is unchanged between years $t$ and $t+1$. 